\title{
Protected Areas Isolation in the Chaco Region, Argentina
}

\author{
Silvia D. Matteucci ${ }^{1} \&$ Micaela Camino ${ }^{2}$ \\ ${ }^{1}$ National Research Council of Argentina, Landscape Ecology and Environment Team, Buenos Aires University, \\ Argentina \\ ${ }^{2}$ Landscape Ecology and Environment Team, Buenos Aires University, Argentina \\ Correspondence: Silvia D. Matteucci, GEPAMA, Buenos Aires University, Buenos Aires C1428EGA, Argentina. \\ Tel: 54-11-4552-9636. E-mail: sdmatteucci@conicet.gov.ar \& smatt03@gmail.com
}

Received: May 17, 2012 Accepted: June 4, 2012 Online Published: June 18, 2012

doi:10.5539/jgg.v4n3p15 URL: http://dx.doi.org/10.5539/jgg.v4n3p15

\begin{abstract}
There is a general concern with regards to effectiveness of protected areas due to their progressive isolation caused by massive land use change in their surroundings. We examined the extent of natural vegetation fragmentation both within and around two protected areas over a period of 32 years, in the Argentine Chaco Region, in two contrasting ecoregions: Humid Chaco and Dry Chaco. We describe type and rate of change around each protected area, and discuss the potential implications for biodiversity conservation on the basis of a percolation/connectivity model for two endemic species. The results show that the rate and type of land use change is unique in each study area, and that the risk of isolation is imminent in both cases. This situation cancels the conservation objectives of protected areas, jeopardizing their effectiveness.
\end{abstract}

Keywords: protected area context, greater ecosystem, land use change, percolation/connectivity

\section{Introduction}

Massive land use change around protected areas threatens the integrity of their ecosystems. Protected areas are usually embedded in larger ecological systems, whose components exchange matter, organisms, information and energy through the borders. Habitat deterioration around the protected areas delays these flows, especially when it does not fulfill all major functions of the greater ecosystem, defined by DeFries, Hansen, Turner, Reid, and Liu (2007) as the wider ecosystem embracing the protected area and its context. Isolation reduces likelihood of exchange across the borders, alters metapopulation dynamics by disconnecting source and sink habitat patches, reduces the amount of habitat for animals that use patches outside the protected area. The proximity of humans accelerates the progress of agricultural and urban frontiers (Curran et al., 2004), increases poaching and illegal fishing within the protected area, and may affect animal population density and dynamics due to hunting or traffic collisions in the outside. Humans and their pollution sources scare off some species of wildlife, and may affect the health of the organisms within the protected area (Liu et al., 2001; Vester et al., 2007).

Scientists have noticed the isolation risk of protected areas since the 1990s, and the number of publications on this issue has increased considerably since then (Hansen \& DeFries, 2007). Studies on effectiveness of protected areas in a fragmented landscape (Kiringe \& Okello, 2007; Ashley, Russell, \& Swallow, 2006), show that there are large differences in their vulnerability, depending on internal (size) and external (location) factors, and on social, economic and political factors (Joppa, Loarie, \& Pimm, 2008). The consensus is that the criterion based on the conservation of 10 to $15 \%$ of the total area to achieve biodiversity conservation has no scientific support (Stewart, Ball, \& Possingham, 2007).

Protected areas offer an opportunity for natural and cultural heritages preservation inside and outside their borders, through the introduction of sustainable management strategies to simultaneously protect biodiversity in the protected area and improve quality of life in their surroundings. To achieve this, one needs to identify and understand the causes of land use change, including social conflicts (DeFries et al., 2007). In most Latin American countries, this knowledge is lacking because sustainable management of natural reserve surroundings is not perceived as a tool for nature conservation within the protected area, nor is it recognized the opportunity for building capacity offered by the presence of local communities.

The Chaco plain is a good example of the likely consequences of land use change on natural and social subsystems, due to the massive land conversion in the last three decades. The Argentine Chaco is part of the Great American 
Chaco, covering over $1000000 \mathrm{~km}^{2}$, between latitude $17^{\circ}$ and $33^{\circ}$ south and longitudes $65^{\circ}$ and $60^{\circ}$ west. It is one of the major wooded grassland areas in South America, in the tropical and subtropical zones of Bolivia, Paraguay, Brazil and Argentina. It houses an exceptional biodiversity, with unique ecological processes.

The Argentine Chaco occupies around $500000 \mathrm{~km}^{2}$, across a wide east-west humidity gradient and north-south temperature gradient. Its main characteristic is the lack of relief, with a regional slope of $0.04 \%$ from east to west. Forests are dominated by three endemic quebracho (ax-breaker) species (Aspidorperma quebracho-blanco; Schinopsis lorentzi, Schinopsis balansae). The Argentine Chaco comprises two ecoregions: Dry Chaco to the west and Humid Chaco to the east (Figure 1). The Dry Chaco ecoregion has mean annual rainfall between 500 and 700 $\mathrm{mm}$, and seven month of water deficit. Intensive riverbed migration shaped its landforms in the post-Pleistocene. High morphological instability, with ancient riverbeds that shift between active and inactive, and natural fire regimes, maintain forested savannas and forests in a climate in which one would expect a desert biome to occur (Morello 1967; Morello \& Adámoli, 1974). The Humid Chaco ecoregion, with a mean annual rainfall of $1200 \mathrm{~mm}$, is covered by a parkland formation, where patches of quebracho forest alternate with open grasslands. Areas dominated by palm trees (Copernicia alba) occupy swampy soils with salt accumulation. Low riparian forests skirt watercourses, and aquatic plants cover flooded areas. Terrain flatness, rain in the upper basin of main rivers, and heavy local seasonal rainfall favor the formation of numerous shallow lagoons that are fringed by bogs.

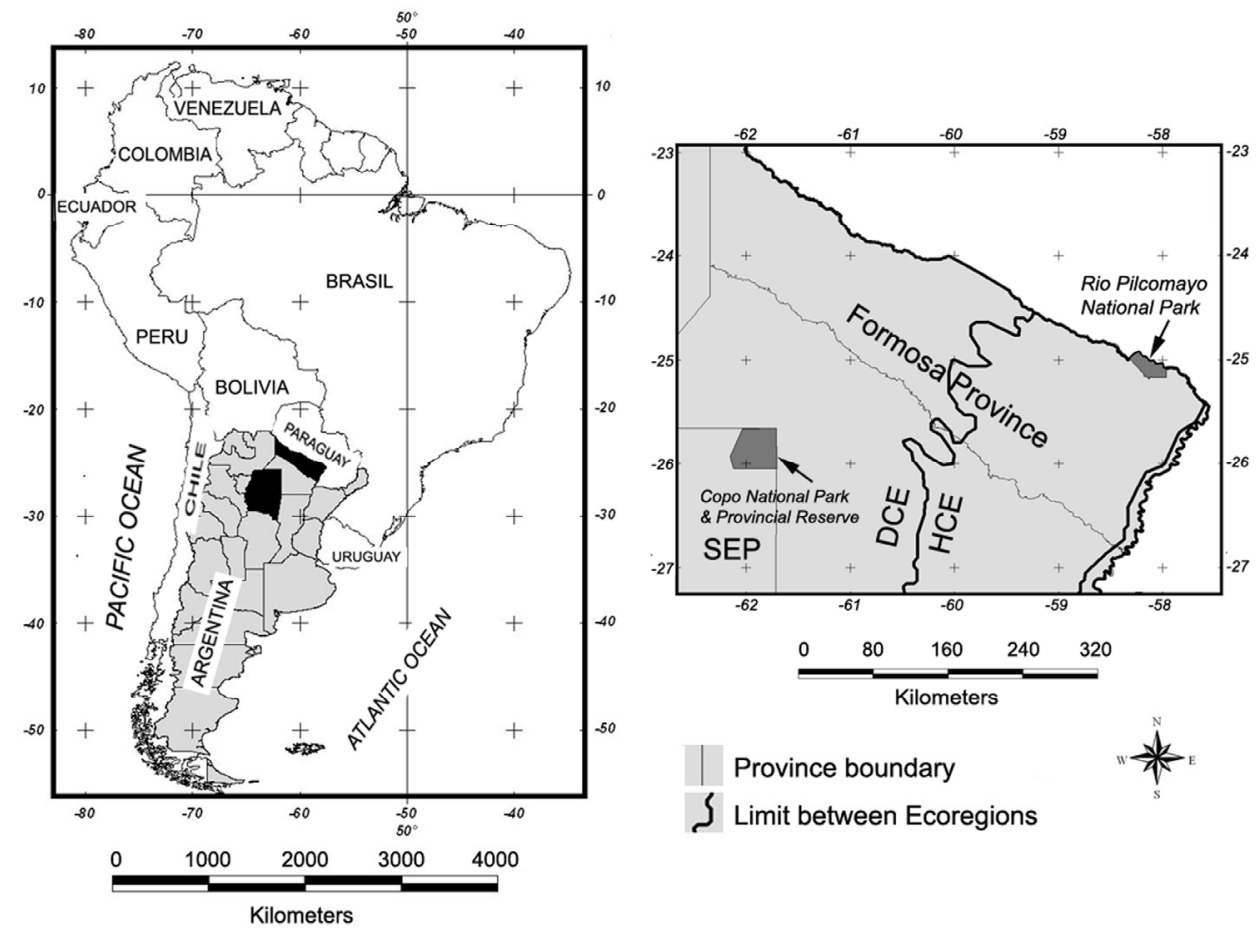

Figure 1. Study area

Left: South America. Argentina in grey, Formosa and Santiago del Estero Provinces in black. Right: Protected areas in dark grey, the black line shows the limits between Cry and Humid Chaco ecoregions, thin grey lines are Province borders.

The impact of human activity in the Argentine Chaco is of long standing (Morello, Pengue, \& Rodriguez, 2007). By the end of the 19th century, the introduction of cattle brought an increase in population and timber requirement for building and energy. At the beginning of the twentieth century, quebracho was used for railway ties and charcoal production; forests were heavily exploited and timber exported for use in the tannin industry in the first half of the 20th century. Cattle ranching have caused shrubland encroachment on grassland. Recent deforestation for soybean cropping, mainly in the Dry Chaco, is causing further fragmentation of forest remnants (Grau, Gasparri, \& Aide, 2005).

There are several features that make the Chaco Region a peculiar complex of ecosystems worthy of protection, 
such as the presence of the three endemic quebracho species, and forests with winter-deciduous trees that mitigate the harsh environment of dry summers in the undergrowth (Caceres \& Sanchez, 2004). The Chaco region may provide invaluable genetic resources for tropical zones that may become increasingly hot and arid, as various scenarios of global warming have predicted (Redford, Taber, \& Simonetti, 1990). Among these genetic resources there are species of quebracho and the chacoan peccary. The large and medium-sized mammal biodiversity compares favorably with that of the tropical rainforest (Redford et al., 1990). Its ecosystems are highly vulnerable to degrading human activities, such as massive tree felling, overgrazing, and forest conversion into cropping. Finally, the Chaco region houses several unique aboriginal cultures whose management strategies are adjusted to the environmental conditions (Alcorn, Zarzycki, \& de la Cruz, 2007).

In the last two decades, agricultural expansion driven by modern agribusiness enterprises oriented to the soybean international market (Gasparri \& Grau, 2009) has accelerated the continuous loss of natural and cultural heritage suffered by the region for more than a century. In the Humid Chaco, only $7 \%$ of the area is suitable for agricultural use. The main activity has been cattle ranching, and subsistence cropping of a great variety of cultivated species. There is a small proportion of agricultural lands on higher elevations, thus agricultural expansion is not as aggressive as in the Dry Chaco. However, soybean cropping has recently displaced some of the aboriginal and other small communities, and it has reduced crop diversity.

In this study, we used various landscape metrics to examine the extent of natural vegetation fragmentation both within and around two protected areas over a period of 32 years. Evidence is provided regarding the risk of protected area isolation in the Argentine Chaco Region, in two contrasting ecoregions: Humid Chaco and Dry Chaco. We describe the types and rates of change around each protected area. A percolation/connectivity model was developed for two endemic animal species to show the potential implications of isolation for biodiversity conservation.

\section{Methods}

\subsection{The Study Areas}

We chose two study areas in contrasting ecoregions of the Argentine Great Chaco: Copo area comprises the National Park, the Provincial Reserve and their surroundings (from now on, Copo) in the Dry Chaco ecoregion, and the Pilcomayo area includes the National Park and its surroundings (from now on, Pilcomayo) in the Humid Chaco ecoregion (Figure 1). Only $6.41 \%$ of the Dry Chaco and 3.26\% of the Humid Chaco are under protection in several National Parks and other reserves (Burkart, 2007).

Copo National Park, located in Santiago del Estero Province, has an extension of $1142.5 \mathrm{~km}^{2}$. Provincial authority created a natural reserve in 1968, and in 2000, it was transferred to the national jurisdiction. Its main objective was the protection of endangered species, such as jaguar (Panthera onca), giant anteater (Myrmecophaga tridactyla), giant armadillo (Priodontes maximus), and chacoan peccary (Catagonus wagneri), and of quebracho forests. Side by side to the west of the National Park is the Provincial Reserve of $850 \mathrm{~km}^{2}$, established in 2002 for multiple uses. This study area comprises the National Park and the Provincial Reserve (Copo PA), and their surroundings.

The outstanding feature of Copo is its peculiar landscape, consisting of a large plain of very gentle slope and sluggish watercourses draining to the southeast. Parallel strips of grassland and shrubland in ancient watercourses filled in with sand traverse the open forest matrix. Quebracho blanco (Aspidorperma quebracho-blanco), quebracho colorado santiagueño (Schinopsis lorentzii) and mistol (Ziziphus mistol) are the most frequent forest species. Distinctive patches of burned vegetation stretching in a south-north direction, originated by natural and human fires, interrupt both physiognomies.

Río Pilcomayo NP, nearly $520 \mathrm{~km}^{2}$, was established in 1951 to preserve a wilderness section of the Humid Chaco ecoregion, and protect its genetic diversity and plant and animal assemblages. Among the fauna there are three monkey species (Cebus nigritus, Alouata caraya, and Aotus azarai azarai), the aguara guazu or maned wolf (Chrysocyon brachyurus), carpincho (Hydrochaeris hydrochaeris), several species of caiman, aquatic birds, including the muitu (Crax fasciolata), which is threatened by local extinction since it is present only in the National Park.

The main landscape feature of the Pilcomayo is the great abundance of rivers, swamps, natural levees, oxbow lakes, and its dense vegetation cover that strongly contrasts with the marked aridity of the Dry Chaco. The vegetation forms a tangled mosaic of palm savanna and dense forest patches, spotted with marshes, lagoons, flooded riverside forests, forested levees, and back swamp forests, with or without quebracho species. It is characterized by an alternating flood and drought regime, and many species are adapted to the natural rhythm of alternating wet and dry periods. In 1992, the Río Pilcomayo NP was included in the list of Wetlands of International Importance 
(Ramsar Convention), for its value as habitat for aquatic species.

\subsection{Datasets}

In order to evaluate type and rate of land use change, we chose landscape elements easily identified on satellite images, such as human corridors, urban patches, and crop parcels. Forest fragments in Pilcomayo were also considered because they show high contrast with surrounding land cover physiognomies. The chosen landscape elements are visible in all images, regardless of the sensor, date of capture and landscape feature.

Maps of the landscape elements were produced using an object-oriented strategy, based on cloud free MSS, TM and ETM+ Landsat imaginery of four dates for each study area: 1976, 1988-91; 2000-01 y 2007 for Copo; 1975, 1987-89; 2000 y 2007 for Pilcomayo. Human corridors, parcels and urban patches were manually digitized on screen with the satellite images as backdrop. The forest fragments in Pilcomayo were delimited with the "Find like areas" extension of ArcView software. This extension operates using training data to perform a supervised classification of a single class. Core areas of forest patches were used as training data. Structural landscape metrics were calculated from the digitized maps for each date and each landscape element.

Connectivity/percolation was approached from the perspective of one species in each area: the owl monkey (Aotus azarai azarai) in Pilcomayo, and the chacoan peccary (Catagonus wagneri) in Copo. Both species are endemic to the Great Chaco, they are considered endangered but are still present in the study areas, data about their home range size in our study area are available, and they use forests or woodlands as their habitat. We recognize that this is a simplified exercise, and that it has no application for conservation management since these species are not umbrella species; however, the model fulfills our objective of examining isolation risk of protected areas.

The input data for connectivity measurement was a raster habitat map with each grid cell assigned a value of one to habitat cells and zero to cells that were considered non-habitat, for both study areas. This binary map assumes that the non-habitat cover behaves in an ecologically neutral way, which is not the case for most species. The owl monkey lives within the forest, and the non-habitat is a hostile environment; however, the chacoan peccary could traverse grasslands though with high risk of being hunted. A theoretical landscape model (TLM) with minimum human impact was constructed for each study area, to represent the situation before the 20th century, when human impact was low. This model was used to assess changes in connectivity due to human activity in 1987-89 and 2007.

In Pilcomayo, the TLM was obtained by calculating a maximum neighborhood statistics in a $3 \times 3$ cells kernel on the 1987-89 habitat map. In the resulting map, habitat fragmentation caused by roads and single non-habitat pixels within habitat patches disappeared. A one-pixel border was added to all habitat patches to account for edge erosion. The spatial arrangement of forest patches was not changed. The map had a 30 × $30 \mathrm{~m}$ resolution.

In Copo, the model map was obtained from the 1988-1989 land cover map, derived from unsupervised classification of the satellite images in ten land cover classes. A recent vegetation map of Copo PA provided by the Administration of National Parks (Caziani et al., 2003) was used to aggregate the 10 classes into five cover types: dense forest, open forest with emergent trees, woodland, grassland and denuded surfaces. A 3 x 3 cells kernel filtering was performed to eliminate noise (isolated pixels). The map was reclassified in habitat (forests and woodlands) and non-habitat (grasslands, denuded soils), since the chacoan peccary prefers forests and woodlands as habitat, and is less frequently seen in grasslands (Altrichter \& Boaglio, 2004). In order to reduce data set size, we resampled the map to obtain a $50 \mathrm{~m}$ resolution grid map. Human corridors, parcels and urban patches in 1976 were compiled in a polygon map, which was used to remove humanized elements from the habitat map.

\subsection{Sampling Design}

Land use change was assessed within buffer zones delineated arround each protected area. We chose a fixed $10 \mathrm{~km}$ width buffer to minimize border effects caused by patch truncation, and to keep constant the border effect. The buffering analysis provided six groups of land cover and landscape context information, including the protected area and five buffer zones. The procedure aimed at exploring the magnitude and sequence of land cover change with increasing distance from the protected area. The buffer zones are of varying size because their extension increases with distance. Thus, metric values were estimated relative to each buffer zone area.

Percolation/connectivity was assessed in a buffer zone of $50 \mathrm{~km}$ wide around Copo PA and $30 \mathrm{~km}$ wide around Río Pilcomayo NP. The $30 \mathrm{~km}$ buffer around Rio Pílcomayo NP includes the fringe of urban growth along the National Route, where all forest patches appeared truncated in the 2007 image. In Copo, a $50 \mathrm{~km}$ buffer captures land use change at the furthest distance from the protected area border. In both cases, connectivity within the protected areas was also calculated in order to evaluate their effectiveness in conserving habitat spatial extent. Connectivity is scale-sensitive, and values for the study area cannot be compared to values for the protected area. For the same reason, differences between narrower buffers may mask the effect of land use change if large patches become 
truncated at buffer borders; thus, we performed the analysis in a single wide buffer, which allows us to examine temporal changes.

\subsection{Indicators of Land Conversion and Calculation of Landscape Metrics}

Human corridors are all the constructed structures that divide the space into plots with the same content on both sides; i.e., they dissect the natural vegetation cover. They include mostly roads and plot edges marked for future conversion to agriculture or forestry. The demarcation of plots well in advance of land conversion is a common event in the Chaco region. Human corridors are straight, except in the case of roads linking small villages. Rivers and streams were not considered landscape dissections, since they are part of the natural landscape. Human corridors are one of the most harmful forms of fragmentation (Trombulak \& Frissel, 2000). They disrupt water flow and movement of organisms, and facilitate water erosion and introduction of exotic species. When a landscape is dissected, land conversion is expected through urban expansion along dissections, or through land conversion to agriculture or forestry. Roads have been identified as relevant indicators of integrity loss of ecosystems (Noss \& Cooperrider, 1994).

Urban areas include human settlements of various characteristics, from small scattered villages to dense cities with their suburban areas and periurban fringe. Large cities show a dense center, a suburb and a periurban fringe. The periurban is a mosaic of constructed plots, small horticultural parcels, junkyards, poultry farms, slaughterhouses, small industries, etc., with no characteristic spatial pattern, except for the variability in plot size and the irregularity of spatial configuration.

Crop parcels are larger than periurban plots, and are identified by their regular geometric shape, and by their content, which differs from the forest or savanna. The content may be active crops, fallow lands, or dismantled vegetation ready to be sown.

We measured metrics of constructed elements with Patch Analyst extension in ArcView 3.3. The metrics were human corridor density (HCD) as total length in relation to area; patch density (PD) as number of patches per unit area; proportion of land occupied by each land use type (PLAND) as land use type area divided by total unit area.

We used the correlation length (CL) to quantify habitat connectivity. CL is a mathematical representation derived from percolation theory, and assesses the average distance that a randomly placed individual can disperse until it reaches a habitat border. Low values indicate isolated habitat patches, whereas high values result from a percolating patch expanding across the study area. CL is computed as the area-weighted average of the patch radius of gyration, which is the mean distance between each cell in the patch and the patch centroid. We calculated radius of gyration and patch size with Fragstats version 3 (McGarigal, Marks, Holms, \& Ene, 2002) using as an input the raster map exported from ArcView in ASCII format. Correlation length was calculated in a spreadsheet, by summing up the area weighted patch radius of gyration. The area-weighted radius of gyration of a patch is obtained by multiplying the patch radius of gyration by the fraction of the total habitat area in the patch (Area of patch/Total habitat area). The sum includes all patches larger than the minimum home range size for the species, which is of 4 ha for the owl monkey (Fernández-Duque, 2009) and 600 ha for the chacoan peccary (Taber, 1993). Total habitat area, habitat patch number and largest habitat patch index (LPHI) were also calculated. LPHI represents the percentage of the total habitat area in the largest habitat patch.

\section{Results}

\subsection{The Landscape Dissection Process}

In both study areas, an increase in the total extent of human corridors was observed. In Copo the total length almost quadrupled in the first 25 years, from 2,492 km in 1975 to $9,925 \mathrm{~km}$ in 2000. In Pilcomayo, where corridors are less developed, the value more than tripled in 32 years, $601 \mathrm{~km}$ in 1975 to 1,986 km in 2007. In both study areas, corridor density was less than $100 \mathrm{~m} / \mathrm{km}^{2}$ at the beginning of the study period. In Pilcomayo, density increased steadily along the 32 years. In Copo, density peaked in 2001, and declined in 2007. Both study areas were traversed by main national and provincial roads at the beginning of the study period, and new connections between villages and trails entering new agricultural parcels were later constructed. Thus, mean length of human corridors decreased, while their number increased. In Copo, many of the corridors established during the 1980's were afterward fragmented by the conversion to agriculture, and corridors mean length and number decreased in the last period.

Human corridor density tended to increase around protected areas and in all buffer zones along the study period. In Copo, the largest increment occurred between 1976 and 1988 at all distances (Figure 2a). The decrease in the last period was due to the conversion to agriculture of previously demarcated plots, a process that occurred at all distances but in a higher proportion at $20 \mathrm{~km}$ or more from the PA border. In Pilcomayo, corridor density was 
higher near the protected area than further away (Figure 2b). It also increased within the National Park in the last period due to the construction of a road connecting the national route with the main river as a tourist facility.
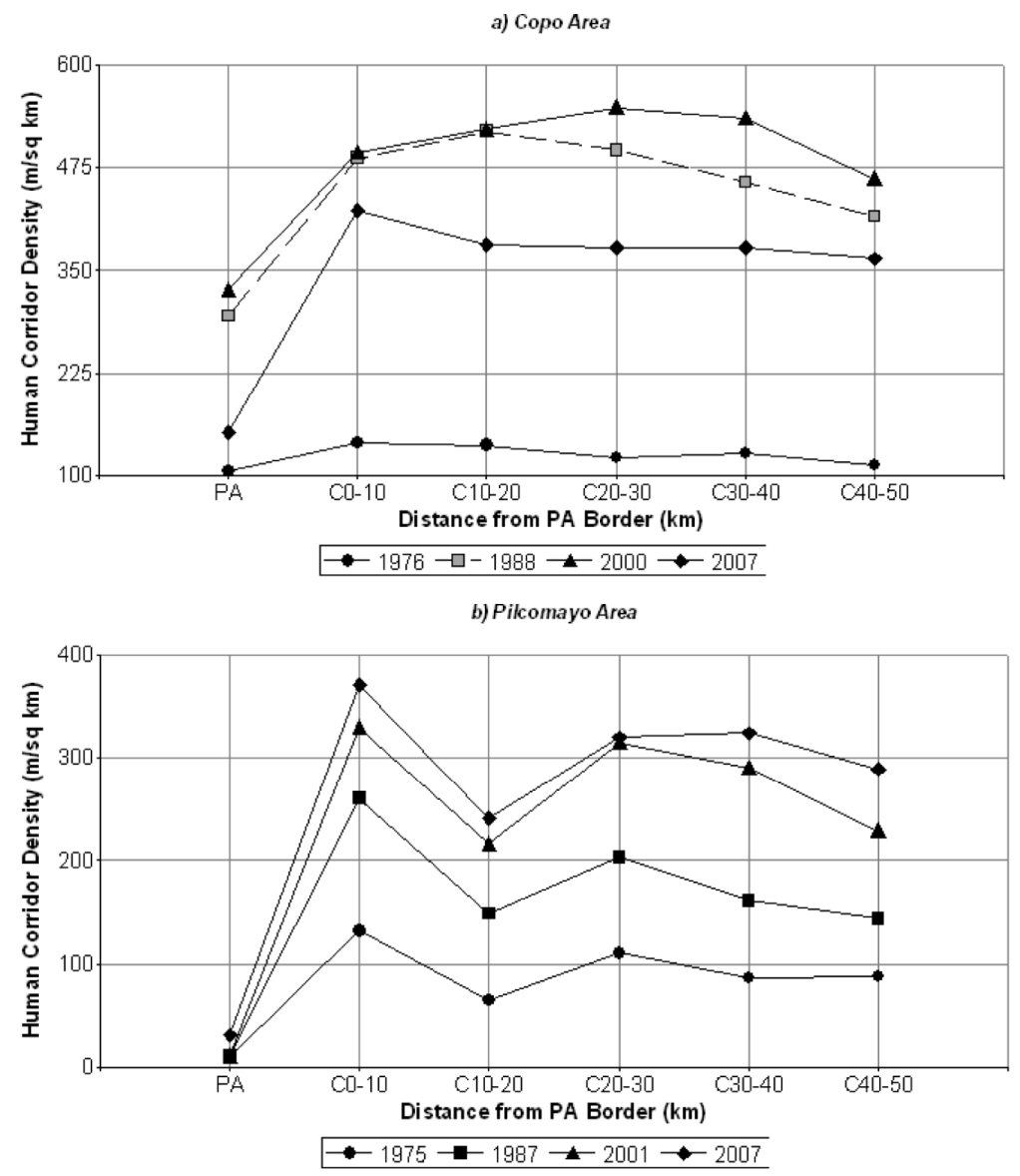

Figure 2. Change in density of human corridors in space and time

Human corridor density within the protected area and in each buffer zone is shown for each year.

\subsection{Urban Expansion}

At the beginning of the study period, urban settlement number was over 13 times higher in Copo than in Pilcomayo (136 to 10); however, total area, patch density and mean patch size were higher in Pilcomayo. In Copo most of the 136 urban patches were small villages, including single house settlements (posts), with a total area of $63.21 \mathrm{~km}^{2}$ and PLAND of $0.31 \%$. The few middle size cities were located along the national route that traverses the region in a NW-SE direction. These were relatively small settlements with reduced suburban and periurban fringes. From 1988 to 2000, urban expansion almost duplicated $\left(133.59 \mathrm{~km}^{2}\right)$, mostly along the route, and urban patch number increased to 204. In Pilcomayo, the 10 urban patches present at the beginning were large settlements, with a very dense impervious nucleus surrounded by suburban areas occupying around $95 \%$ of the patch area. These settlements lay along the national route, which runs very near the National Park border. Urban total area and PLAND were $796 \mathrm{~km}^{2}$ and $11.5 \%$, respectively. From these cities, a corridor type expansion (Forman, 1995) took place from 1975 on, new villages and posts appeared, and the periurban zone expanded to $70 \%$ of the urban patch area. From 2000 to 2007, very small urban patches appeared to the south, patch number increased with very little increase in total urban area. To the north, the urban area formed a wide strip along the National Route and spread to the south along two provincial roads.

In Copo, the percentage of buffer land occupied by urban patches was very low as compared to Pilcomayo. Urban expansion occurred in all buffer zones and within the protected area, but the larger increments occurred at a distance of 10 to $20 \mathrm{~km}$ from the border (Figure 3a). Within the protected area, urban expansion was observed in the Provincial Reserve, caused by the establishment of loggers' posts, which disappeared between 2000 and 2007 
together with human corridors, after it was officially established as a protected area. In this last period, urban area decreased slightly at all distances, due to encroachment of agriculture on small villages and posts. In Pilcomayo, the percentage of land occupied by urban settlements was very small in all buffer zones in 1975. Urban expansion occurred at all distances, but it was higher next to the protected area, and it decreased with distance from its border. The highest increment took place between 1975 and 1987; by 2007 urban expansion seemed to have ceased at all distances (Figure 3b).
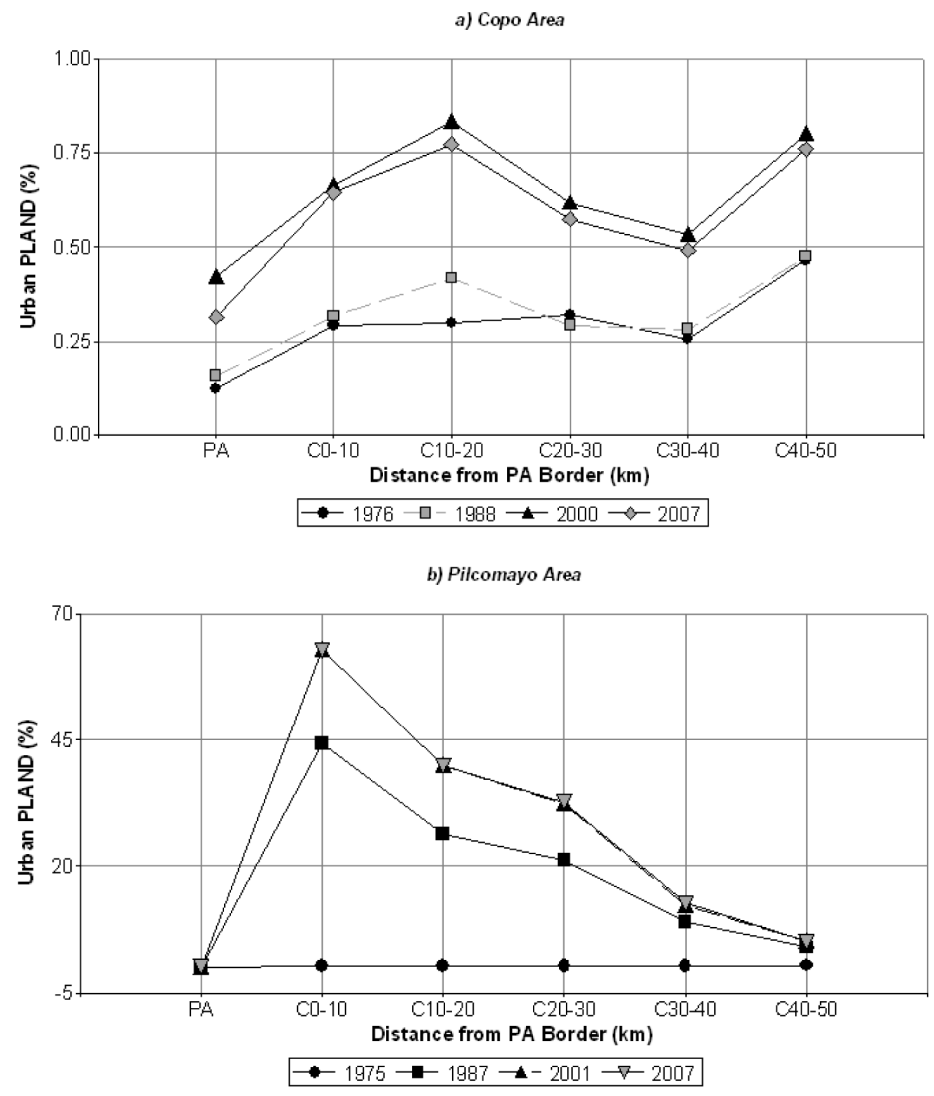

Figure 3. Change in percentage of urban area in space and time

Percentage of total area (PLAND) occupied by urban land use in the protected area and in each buffer zone is shown for each year.

\subsection{Agricultural Expansion}

Agricultural plot total area and number increased during the study period in both study areas; however, in Copo both metrics have higher values than in Pilcomayo. At the beginning of the study period, total area was 27.23 and $15.7 \mathrm{~km}^{2}$ in Copo and in Pilcomayo; in 32 years these numbers were 1861.1 and $104.28 \mathrm{~km}^{2}$, respectively. The percentage of parceled land was almost the same in both areas in the 1970's, however, in Copo it increased more than in Pilcomayo. In Pilcomayo, agricultural expansion did not follow a pattern. Plots established between 1975 and 1987 disappeared in the following period, and new locations were parceled. Between 1987 and 2001 a few plots enlarged, and new large plots arose elsewhere. The small total area is a consequence of the low productivity capacity of soils for commercial crops, and the shifting of parcel location may be explained by alternating dry and flood periods, and fire occurrence.

In both study areas agricultural expansion occurred at larger rate far from the protected area borders (Figure 4). In Copo, the total area occupied by crop parcels was small in 1976 at all distances, and it increased substantially along 32 years in all the buffer zones. Agriculture expanded towards the protected area (Figure 4a). In Pilcomayo, the spatial and time patterns of total agricultural land area was not evident. In 1975 total area peaked between 40 and $50 \mathrm{~km}$ from the reserve border; in 1988 the peak had shifted to the third buffer ring (20 to $30 \mathrm{~km}$ ), and in 2001 and 2007, the largest extension occurred in the fourth buffer ring (Figure 4b). This is explained by the shifting of plot location mentioned above. 

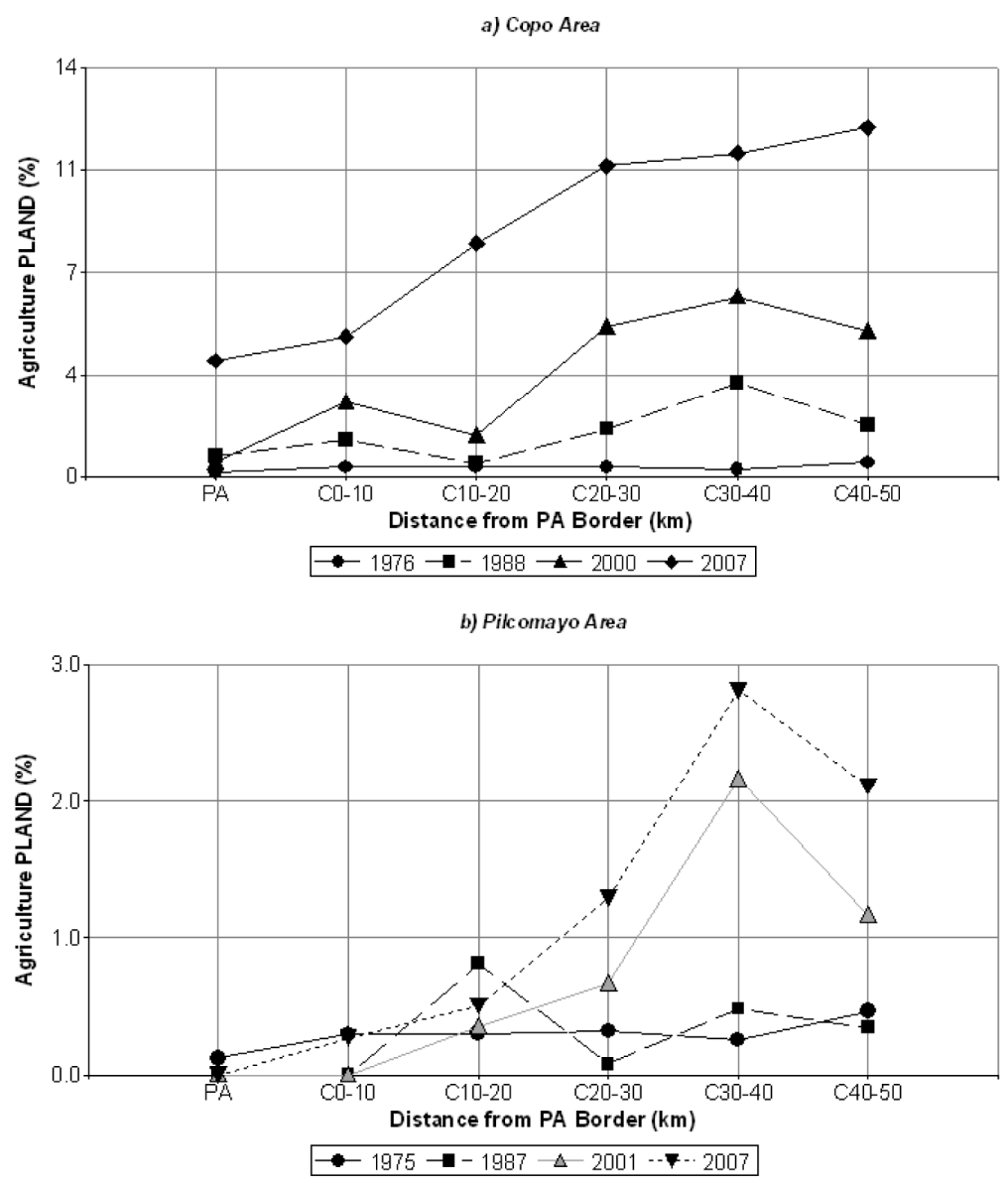

Figure 4. Change in percentage of cropland area in space and time

Percentage of agricultural cover (PLAND) within the protected area and in each buffer zone.

\subsection{Forest Patch Conversion in the Pilcomayo Area}

Closed forest patch number and size, and total forest area decreased considerably during the study period. In 1975, total area was $1304 \mathrm{~km}^{2}$ distributed in 13,304 patches. In 32 years, total area was reduced in $69 \%$ and patch number in $34 \%$. Patch size also decreased considerably. Since agriculture has always been a minor activity, the impact on dense forest cover was a consequence of urban expansion.

In 1975, forests covered large extensions and patch distribution was homogeneous in the study area. The lower PLAND in the first buffer zone ( 0 to $10 \mathrm{~km}$ from the National Park border) coincides with the presence of the National Route, and the more intense urban development around it. Forest percent cover decreased within the protected area and at all distances, but at a higher rate near the National Park (Figure 5a). Forest loss occurred earlier next to the protected area, and it is highest next to the National Park between 1975 and 1987. Forest patch density increased between 1987 and 2001 due to fragmentation of the remnant patches. Later some patches disappeared and density decreased again. Thus, fragmentation and disappearance of the smaller patches caused alternating increments and reductions of patch number. This happened at all distances, but the process fades away with distance. Within the National Park there was some fragmentation in the first 26 years, and patch loss from 2001 to 2007 (Figure 5b). 

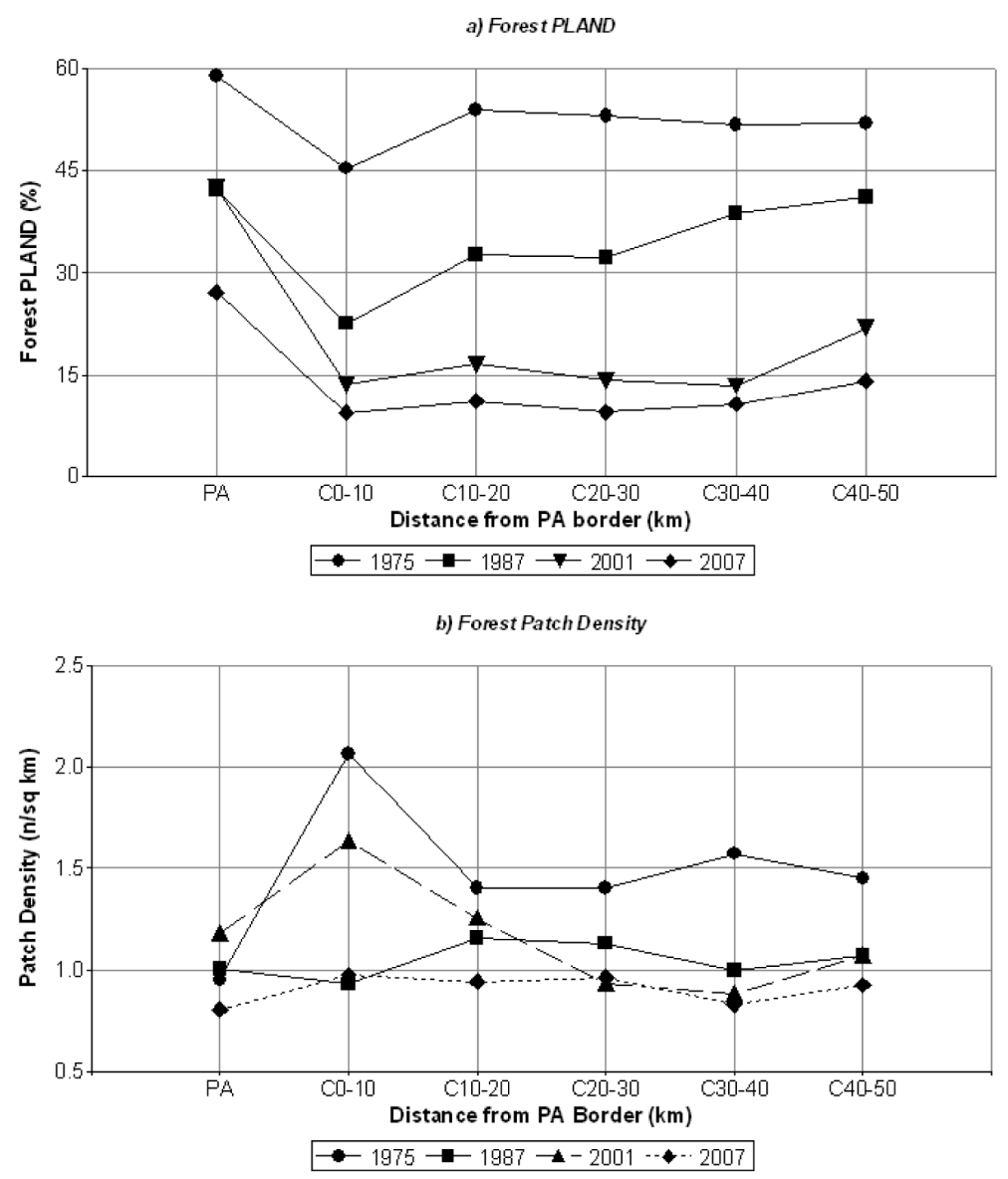

Figure 5. Change in forest percent cover (a) and patch density (b) in space and time Percentage of forest land cover, and patch density in the protected area, and in each buffer zone.

\subsection{Habitat Connectivity}

In both study areas, correlation length (CL) is substantially lower in the real landscapes than in the theoretical landscape model, and it decreases in the 20 years span of our study. As total habitat area decreases, there is a decreasing likelihood that habitat patches will merge and expand over the landscape. This is confirmed by the largest habitat patch index (LPHI), which decreases as CL decreases.

In Pilcomayo, CL is 64\% lower than in the theoretical landscape model by 1987 and even lower in 2007 (Table 1). In 1987, the LPHI is 50\% lower than in the model landscape, and both total habitat area and number of patches decrease. Even though there are more habitat patches in 2007 than in 1987, CL decreases in about 36\% in relation to the value in 1987. The results show that urban growth, which is the mayor form of land use change, affects habitat connectivity. We do not know which is the minimum habitat area required to maintain a viable population of owl monkey, or if all habitat patches are occupied; we know that their median maximum natal dispersal distance is around $650 \mathrm{~m}$ (Fernandez-Duque, 2009). Until 2007 there was enough habitat space to allow survival and avoid inbreeding. Availability of space does not ensure the persistence of a minimum viable population, but it suggests that a study of dispersion behavior of owl monkeys in Pilcomayo is worthwhile. 
Table 1. Correlation length and supplementary landscape metrics, in Copo and Pilcomayo

\begin{tabular}{|c|c|c|c|c|c|c|}
\hline & \multirow[b]{2}{*}{ Landscape Metric } & \multicolumn{3}{|c|}{ Study area } & \multicolumn{2}{|c|}{ Protected Area } \\
\hline & & TLM & $1988 / 87$ & 2007 & 1988/87 & 2007 \\
\hline \multirow{4}{*}{ ঠ̊ } & Total habitat area (sq km) & $12,909.68$ & 9473.6 & 7754.22 & 1715.78 & 1714.39 \\
\hline & Number of patches & 40 & 291 & 214 & 22 & 19 \\
\hline & LHPI (\%) & 71.28 & 10.71 & 13.76 & 59.18 & 65.25 \\
\hline & Correlation length (m) & $32,334.82$ & 4281.91 & 5187.03 & 9168.95 & $10,326.05$ \\
\hline \multirow{4}{*}{ 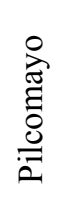 } & Total habitat area (sq km) & 893.56 & 536.32 & 425 & 144.11 & 86.13 \\
\hline & Number of patches & 1126 & 958 & 1103 & 176 & 171 \\
\hline & LHPI (\%) & 41.95 & 21.45 & 14.2 & 45.07 & 7.58 \\
\hline & Correlation length (m) & $11,524.63$ & 4102.49 & 2619.14 & 3275.22 & 866.05 \\
\hline
\end{tabular}

The Study area comprises the protected area and the $30 \mathrm{~km}$ buffer. TLM: theoretical landscape model. Columns 2 to 4: Values in the study area, for the model landscape, and for initial and final years. Initial years are 1988 for Copo and 1987 for Pilcomayo. Columns 5 and 6: Values in the National Park area, for initial and final years. LHPI (Largest habitat patch index) represents percent of total habitat in the largest patch. Comparison across areas is not valid (see text for explanation).

In Rio Pilcomayo NP, CL and the LHPI decreased considerably in 20 years; however, number of patches is almost the same. This indicates the occurrence of patch edge erosion. It appears that the protected area has not been effective in the conservation of habitat quality.

In Copo, the results show considerable fragmentation caused by landscape dissection when comparing the theoretical landscape model to the 1988 land use cover. Habitat patch number increased over seven times, and the fraction of habitat in the largest patch decreased by almost seven times. Changes in these metrics result in a decreased CL of almost eight times. This may be the reason why jaguar has not been found recently, and the chacoan peccary population seems to be declining due to subsistence hunting (Altrichter, 2005). Between 1988 and 2007, habitat area decreased further, but the fraction of habitat in the largest patch and CL show a slight increase, probably because of an intensified control and forest recovery since 2000, when the reserve was transferred to the National jurisdiction. In the protected area, changes have been very slight in the almost 20 year span of our study, showing that it has been effective in habitat protection.

\section{Discussion}

The results show that land use change around the protected areas puts them at risk of ecological isolation. There are great differences between the study areas concerning type and rate of land use change. Differences between areas are a consequence of differences in biogeophysical, socioeconomic and political factors, as was reported for other regions (Joppa et al., 2008).

The demographic censuses for 1980, 1991 and 2001, used to estimate population in 2007 and 1975 at the county level, and in the study area, show a population increase of 1.9 in Pilcomayo and 2.2 in Copo, from 1975/76 to 2007. However, in 2001 total population in Copo was much lower than in Pilcomayo (44,322 and 104,675 inhabitants, respectively); which shows the rural nature of Copo and the urban nature of Pilcomayo.

Copo is more vulnerable to changes in land use than Pilcomayo, according to the rate of increase in human corridor density. In both areas human population and urban area increased in parallel (Figure 6), however in Copo both variables are smaller than in Pilcomayo.

Around Copo, the increase in human corridor total length between 1976 and 1988 is followed by an increase in agricultural plot total area in the following period (Figure 6a), attesting to the suggestion that landscape dissection predicts future land use change. Thus, in Copo, isolation risk comes mainly from agricultural expansion. During the first 12 years, human population increased at lower rates and in parallel to agricultural expansion. In the next 12 years population increased faster, while agricultural expansion continues increasing at a higher rate (Figure 6a). In the last seven years, rate of agricultural expansion continues high while population growth tends to level off, probably because subsistence cropping and family enterprises give way to industrial soybean cropping in large extensions. 
The situation of Río Pilcomayo NP is critical because urban growth is taking place within a few meters to $20 \mathrm{~km}$ from its border; at some points urban settlements were at $200 \mathrm{~m}$ of the border in 2007 , and they were at less than 1 $\mathrm{km}$ at several points in its southern edge. Forest loss is associated with urban growth (Figure 6b), and the impact of human corridors on forest fragmentation is masked by the large magnitude of urban expansion. Human population increases at almost the same rate as urban growth along 32 years. Even though agricultural expansion is not a threat in Pilcomayo, it may become so in a near future, given the great impulse of agribusiness enterprises (Gasparri \& Grau, 2009).
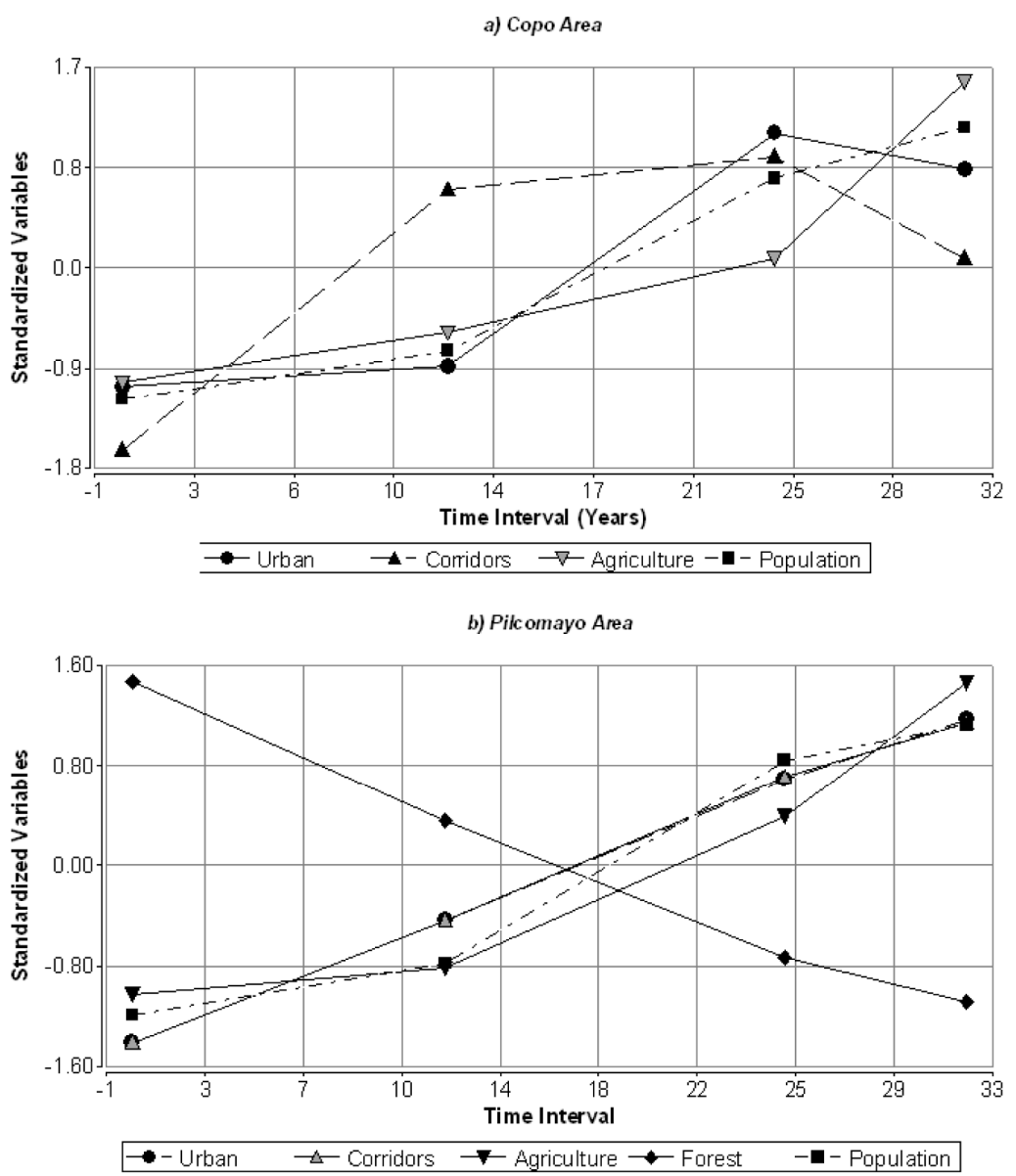

Figure 6. Change Tendency

Metric values were standardized to mean 0 and standard deviation 1, in order to compare indicator tendencies.

\subsection{Representativeness and Effectiveness}

Representativeness refers to the need for reserves to sample the full variety of biodiversity (Pressey, Humphries, Margules, Vane-Wright, \& Williams, 1993). The choice of the sample is a decision to take at the time of planning a protected area and selecting its location. From a functional point of view, representativeness is achieved when the greater ecosystem is fully sampled (DeFries et al., 2007). In Argentina, the establishment of protected areas has been based on opportunity rather than on a regional planning process (Burkart, 2007). It seems that none of our study areas fulfills the requirement of representativeness. Copo protected area and Río Pilcomayo National Park comprise 3.3 and $1.1 \%$ of their greater ecosystems, respectively. In both cases, the representativeness seems very low. Both protected areas are located in the center of elongated ecosystems characterized by strong climatic and hydrologic gradients along their longest axis, and most likely they do not represent the whole ecocline. The lack of representativeness can be avoided by designing nature reserve networks connecting habitat patches along the full environmental gradient.

Effectiveness is defined as the successful conservation of biodiversity, or the fulfillment of whatever the protected area objective is. A full range of methods has been developed to assess protected area effectiveness for a wide 
scope of purposes (Bruner, Gullison, Rice, \& da Fonseca, 2001). Effectiveness is assessed in relation to the protected area objectives; if objectives are fulfilled, the protected area and its management are effective. Río Pilcomayo NP was created to preserve a wilderness section of the Humid Chaco ecoregion, but no explicit statement is made of the species, populations, landscapes or landscape elements as targets of the conservation plan. The lack of a clear choice of conservation targets and goals hinders effectiveness assessment. The conservation target of Copo PA is a set of endangered animal species and the quebracho forests. However, effectiveness cannot be assessed because there is scarce information on species dispersal behavior, habitat use, population size, and source-sink relationships. This knowledge is essential to design management strategies within and outside the protected areas, especially for the establishment of nature reserves networks covering the whole climatic gradient.

Representativeness and effectiveness may change in time due to natural and human-induced landscape dynamics, thus long term monitoring is essential. In the Argentine Great Chaco the biodiversity conservation process is limited to the demarcation of a reserve and the preparation and implementation of a management plan, no monitoring is done.

In view of the massive land conversion outside the protected areas, permanent updating of the initial diagnosis is a must. The large urban area located south of Río Pilcomayo NP has encroached on a large mosaic of the eastern Chaco, in which wetlands, grasslands and fertile soil patches intermingle. These formations can have source-sink relations with those inside the protected area. Resident species in the National Park may use uplands outside, and if these have been converted to agriculture, habitat and resource availability may be reduced for them. Proximity of humans outside the protected area is another cause of ecosystem deterioration within the reserve. Incursions for poaching, firewood gathering and other activities are inevitable; large animals are in competition with humans, and habitat is lost for small animals (Woodroffe \& Ginzberg, 1998). In Copo PA, high human corridor density and increase use of motorcycles, facilitates a higher accessibility to forests and higher risk of collisions, poaching, and live-animal hunting for the pet market.

If we define effectiveness as the successful conservation and regeneration of natural land cover within the protected areas, Copo has been effective in both objectives, as shown by connectivity measurements done along the 20 years of the study period, considering CL change before and after its transfer to the National jurisdiction in 2000. Río Pilcomayo NP has not been as effective in the protection of habitat quality, as shown by the substantial reduction in correlation length and large habitat patch index between 1988 and 2007. From the comparison of within and context conditions, it arises that none of the two protected areas has been effective in conserving habitat extent or quality in their surroundings, as a result of lack of global management policies and appropriate land use allocation.

\section{Acknowledgements}

This study was financed by the National Agency for Scientific and Technological Promotion (FONCYT) PICT2006 No 2450. The National Spatial Commission provided the Landsat ETM scenes. The 1970' and 1980' images were downloaded from the Global Land Cover Facility (http://glcfapp.glcf.umd.edu:8080/esdi/index.jsp).

\section{References}

Alcorn, J. B., Zarzycki, A., \& de la Cruz, L. M. (2007). Case Study Report: Pilcomayo Trinational River Basin, Argentina. GEM-CON-BIO (Governance and Ecosystems Management for the Conservation of Biodiversity). Retrieved July 2009, from http://www.gemconbio.eu/project_results.shtml

Altrichter, M. (2005). The sustainability of subsistence hunting of peccaries in the Argentine Chaco. Biological Conservation, 126, 351-362. http://dx.doi.org/10.1016/j.biocon.2005.06.024

Altrichter, M., \& Boaglio, G. I. (2004). Distribution and relative abundance of peccaries in the Argentine Chaco: associations with human factors. Biological Conservation, 116, 217-225. http://dx.doi.org/10.1016/S0006-3207(03)00192-7

Ashley, R., Russell, D., \& Swallow, B. (2006). The policy terrain in protected area landscapes: challenges for agroforestry in integrated landscape conservation. Biodiversity and Conservation, 15, 663-689. http://dx.doi.org/10.1007/s10531-005-2100-x

Bruner, A. G., Gullison, R. E., Rice, R. E., \& da Fonseca, G. B. (2001). Effectiveness of Parks in Protecting Tropical Biodiversity. Science, 291, 125-128. http://dx.doi.org/10.1126/science.291.5501.125

Burkart, R. (2007). Las áreas protegidas de la Argentina. Herramienta superior para la conservación de nuestro patrimonio natural y cultural. Administración de Parques Nacionales, Buenos Aires. Rerieved from www.parquesnacionales.gov.ar/_OLD/docAP/DocAP.pdf. 
Cáceres, V., \& Sánchez, V. (2004). Phenology and taxonomy of forest species in Formosa Province. School of Natural Resources, Formosa, Argentina. (in Spanish).

Caziani, S., Trucco, C. E., Perovic, P. G., Tálamo, A., Derlindati, E., Adámoli, J., .. Martínez Oliver, M. I. (2003). Linea de base y programa de monitoreo de biodiversidad del Parque Nacional Copo. Universidad Nacional de Salta, Salta Ciudad.

Curran, L. M., Trigg, S. N., McDonald, A. K., Astiani, D., Hardiono, Y. M., Siregar, P., ... Kasischke, E. (2004). Lowland forest loss in protected areas of Indonesian Borneo. Science, 3003, 1000-1003. http://dx.doi.org/10.1126/science.1091714

DeFries, R., Hansen, A., Turner, B. L., Reid, R., \& Liu, J. (2007). Land use change around protected areas: management to balance human needs and ecological function. Ecological Applications, 17(4), 1031-1038. http://dx.doi.org/10.1890/05-1111

Fernandez-Duque, E. (2009). Natal dispersal in monogamous owl monkeys (Aotus azarai) of the Argentinean Chaco. Behaviour, 146(4-5), 583-606. http://dx.doi.org/10.1163/156853908X397925

Forman, R. T. T. (1995). Land mosaics, the ecology of landscapes and regions. Cambridge: Cambridge University Press.

Gasparri, N. I., \& Grau, H. R. (2009). Deforestation and fragmentation of Chaco dry forest in NW Argentina $\begin{array}{lllll}\text { (1972-2007). Forest Ecology and } & \text { Management, }\end{array}$ http://dx.doi.org/10.1016/j.foreco.2009.02.024

Grau, H. R., Gasparri, N. I., \& Aide, T. M. (2005). Agriculture expansion and deforestation in seasonally dry forests of North-west Argentina. Environmental Conservation, 32, 140-148. http://dx.doi.org/10.1017/S0376892905002092

Hansen, A. J., \& DeFries, R. (2007). Land Use Change around Nature Reserves: Implications for Sustaining Biodiversity. Ecological Applications, 17(4), 972-973. http://dx.doi.org/10.1890/05-1112

Joppa, L. N., Loarie, S. R., \& Pimm, S. L. (2008). On the protection of "protected areas". Proceedings of the National Academy of Sciences, 105(18), 6673-6678. http://dx.doi.org/10.1073/pnas.0802471105

Kiringe, J. W., \& Okello, M. M. (2007). Threats and their relative severity to wildlife protected areas of Kenya. Applied Ecology and Environmental Research, 5(2), 49-62.

Liu, J., Linderman, M., Ouyang, Z., An, L., Yang, J., \& Zhang, H. (2001). Ecological degradation in protected areas: the case of Wolong Nature Reserve for giant pandas. Science, 292, 98-101. http://dx.doi.org/10.1126/science.1058104

McGarigal, K., Marks, B. J., Holms, C., \& Ene, E. (2002). Fragstats. Spatial Analysis Program for Quantifying Landscape Structure. Version 3.3. University of Massachussets, Amherst. Retrieved from http://www.umass.edu/landeco/research/fragstats/downloads/fragstats_downloads.html

Morello, J. (1967). Bases para el estudio fitoecológico de los grandes espacios (el Chaco argentino). Ciencia e Investigación, 23, 252-267.

Morello, J., \& Adámoli, J. (1974). Las grandes unidades de vegetación y ambiente del chaco argentino: vegetación y ambiente de la Provincia del Chaco. Serie Fitogeográfica $\mathrm{N}^{\circ} 13$. Instituto Nacional de Tecnología Agropecuaria, Buenos Aires.

Morello, J., Pengue, W., \& Rodriguez, A. F. (2007). Un siglo de cambios de diseño del paisaje: el chaco argentino. In S. D. Matteucci (Ed.) Panorama de la Ecología de Paisajes en Argentinay Paises Sudamericanos, INTA-MAB-SECyT, Buenos Aires. pp. 19-51. Retrieved from http://www.unesco.org.uy/mab/fileadmin/ciencias\%20naturales/mab/PanoramaEcolPaisajes.pdf

Noss, R. F., \& Cooperrider, A. Y. (1994). Saving nature's legacy. Washington D. C.: Island Press.

Pressey, R. L., Humphries, C. J., Margules, C. R., Vane-Wright, R. I., \& Williams, P. H. (1993). Beyond opportunism: key principles for systematic reserve selection. Trends in Ecology and Evolution, 8, 124-128. http://dx.doi.org/10.1016/0169-5347(93)90023-I

Redford, K. H., Taber, A., \& Simonetti, J. A. (1990). There is more to biodiversity than the tropical rainforest. Conservation Biology, 4(3), 328-330. http://dx.doi.org/10.1111/j.1523-1739.1990.tb00296.x 
Stewart, R. R., Ball, I. R., \& Possingham, H. P. (2007). The effect of incremental reserve design and changing reservation goals on the long-term efficiency of reserve systems. Conservation Biology, 21(2), 346-354. http://dx.doi.org/10.1111/j.1523-1739.2006.00618.x

Taber, A. B. (1993). The Chacoan Peccary (Catagonus wagneri). In W. L. R. Oliver (Ed.) Pigs, Peccaries and Hippos: Status survey and conservation action plan, IUCN, Gland, Switzerland, pp. 41-51.

Trombulak, S. C., \& Frissell, C. A. (2000). Review of Ecological Effects of Roads on Terrestrial and Aquatic Communities. Conservation Biology, 14, 18-30. http://dx.doi.org/10.1046/j.1523-1739.2000.99084.x

Vester, H. F. M., Lawrence, D., Eastman, J. R., Turner II, B. L., Calmé, S., Dickson, R., ... Sangermano, F. (2007). Land change in the southern Yucatan and Calakmul Biosphere Reserve: effects on habitat and biodiversity. Ecological Applications, 17(4), 989-1003. http://dx.doi.org/10.1890/05-1106

Woodroffe, R., \& Ginsberg, J. R. (1998). Edge effects and the extinction of populations inside protected areas. Science, 280, 2126-2128. http://dx.doi.org/10.1126/science.280.5372.2126 